\title{
DOMINANCE HIERARCHIES AND STATUS RECOGNITION IN THE THREATENED CRAYFISH AUSTROPOTAMOBIUS ITALICUS
}

\author{
E. TRICARICO, B. RENAI, F. GHERARDI
}

Dipartimento di BiologiaAnimalee Genetica “Leo Pardi”, Via Romana 17, 50125 Firenze, Italy.
$\begin{array}{lr}\text { E-Mail: elena.tricarico@unifi.it } & \\ \text { Reçu le } 8 \text { novembre } 2004 & \text { Received November 8, } 2004 \\ \text { Accepté le } 24 \text { janvier } 2005 & \text { Accepted January 24, } 2005\end{array}$

\section{ABSTRACT}

This study aims at investigating the formation and maintenance of dominance hierarchies in the white-clawed crayfish, Austropotamobius italicus, a threatened species in Italy. To this end, we investigated the behaviour of size-matched pairs of intact males and followed an experimental design composed of three phases: (1) isolation for a week, (2) combat for five days, and (3) experimental phase in Day 6. This latter phase consisted in switching individuals of the same or of a different status between 15 pairs and in leaving the remaining 5 pairs as before. Therefore, we formed pairs composed of unfamiliar (and familiar) opponents having different (and the same) status. The results show that (a) A. italicus establishes stable dominance hierarchies; (b) A. italicus is able to recognise the status, but not the identity, of its rival; and (c) status recognition is associated with "winner and loser" effects.

Key-words: dominance hierarchies, status recognition, Austropotamobius italicus.

\section{HIÉRARCHIES DOMINANTES ET RECONNAISSANCE DU STATUT CHEZ L'ESPÈCE MENACÉE AUSTROPOTAMOBIUS ITALICUS}

\section{RÉSUMÉ}

Cette étude vise à étudier la formation et le maintien des hiérarchies de dominance chez l'écrevisse à pattes blanches, Austropotamobius italicus, une espèce menacée en Italie. Pour cela, nous avons étudié le comportement de paires de mâles intacts de même taille et suivi un protocole expérimental qui se décompose en trois phases : (1) isolement pendant une semaine, (2) combat durant cinq jours, et (3) phase expérimentale le 6 ème jour. Cette dernière phase a consisté en l'interversion d'individus de même statut ou de statuts différents de 15 paires, en laissant les 5 paires restantes inchangées. Nous avons ainsi constitué des paires d'opposants peu familiers (et familiers) de statuts différents ou identiques. Les résultats montrent que (a) $A$. italicus établit une hiérarchie de dominance stable; (b) A. italicus est capable de reconnaître le statut mais pas l'identité de son rival; et (c) la reconnaissance du statut est associée aux effets « gagnant et perdant ». italicus.

Mots-clés: hiérarchie dominante, identification de statut, Austropotamobius 


\section{INTRODUCTION}

Various species of invertebrates are known to form linear dominance hierarchies (reviewed in WILSON, 1975). The emergence of these social relationships is usually accompanied by the reduction in the frequency and intensity of fights between combatants (STEINBERG and CONANT, 1974; HUBER, 1987) and by the generation of a lasting polarity for the outcome of agonistic interactions (FRANCIS, 1998; DREWS, 1993).

Changes in dominant and subordinate behaviour in aquatic invertebrates have been imputed to three possible mechanisms (GHERARDI and DANIELS, 2003). Firstly, a prior winning experience increases, and a prior losing experience decreases, the probability of victories. This leads to "winner and loser effects" (DUGATKIN, 1997), as found in the cuttlefish Sepia officinalis (BOAL, 1996), in which an animal behaves in accordance with its own experience independently of the rival. Secondly, an animal can recognise the status of the opponent by a pheromone, a posture or a behaviour, without any previous direct experience with it, as hypothesised for hermit crabs (Pagurus longicarpus: WINSTON and JACOBSON, 1978) and crayfish (Procambarus clarkii: COPP, 1986; Orconectes rusticus: ZULANDT SCHNEIDER et al., 2001). The third mechanism consists in recognising the previously encountered opponents from chemical or visual cues exclusive to them ("true individual recognition") or proper of one of two categories ("binary individual recognition"; GHERARDI and TIEDEMANN, 2004). Only a few species were suggested to be capable of a form of individual recognition (the crayfish Cambarellus shufeldtii: LOWE, 1956; the hermit crab Pagurus bernhardus: HAZLETT, 1969; the river crab Potamon fluviatile: VANNINI and GHERARDI, 1981; the mantis shrimp Gonodactylus festae: CALDWELL 1979, 1985; the lobster Homarus americanus: KARAVANICH and ATEMA, 1998; the hermit crab Pagurus longicarpus: GHERARDI and TIEDEMANN, 2004). The different mechanisms can however coexist, as hypothesised for Procambarus acutus acutus by GHERARDI and DANIELS (2003).

Aims of this study were to analyse the ability of the white-clawed crayfish, Austropotamobius italicus, to establish dominance hierarchies and to investigate the mechanism/s at the basis of their formation and maintenance, under the rationale that behavioural issues play a major role in conservation biology (SUTHERLAND, 1998). As suggested by several authors (see, e.g., GHERARDI, 2002), ethological studies may in fact help in developing strategies for the preservation of threatened species.

\section{MATERIAL AND METHODS}

\section{Study animals and experimental protocol}

We collected 40 mature males of Austropotamobius italicus (cephalothorax length: 26.73 to $42.80 \mathrm{~mm}$ ) in good conditions (no mutilations or visible diseases) from the streams Rio Meo and Gorandaccio (Prato, Tuscany).

Experiments were carried out between 2002 and 2004 from 10:00 to 18:00 hours. Following in part GHERARDI and DANIELS'protocol (2003), our experimental design was composed of three phases:

(1) One-week isolation. This period was sufficient to remove memory of previous social experiences (GUIASU and DUNHAM, 1999; ZULANDT SCHNEIDER et al., 2001). Crayfish were numbered on the cephalothorax using a white typing correction fluid; they were kept isolated in opaque PVC aquaria $(30 \times 16 \mathrm{~cm})$ and fed twice a week.

(2) Five-day combat. Twenty size-matched pairs (difference in the cephalothorax length: 5-6\%) were kept for an hour per day in an observation container (a circular opaque PVC container, diameter: $30 \mathrm{~cm}$ ). During the one-hour cohabitation, a number 
of parameters were recorded (see below) by an experienced observer (ET). At the end of the observation period, crayfish were inserted back into their individual containers and fed.

(3) Experimental phase (Day 6). Fifteen new pairs of combatants were formed by switching individuals of the same or of a different status between former pairs, while the remaining 5 pairs were left as before. Therefore, we formed 15 pairs of unfamiliar opponents with different ( 5 UN pairs) or with the same status (5 alpha-alpha, AA, and 5 beta-beta, BB, pairs) and 5 pairs composed of the same opponents as in the preceding five days of combat (FA pairs). All the pairs were followed by 1-h observation.

\section{Recorded Data}

Before every 1-h observation, the two opponents were kept in the observation container for 5-min acclimation; during this time, they were separated by an opaque PVC divider. The observation started by removing this divider and consisted in tape-recording the parameters as follows:

(1) Number of interactions. An interaction began when one crayfish approached the rival and ended when one of the opponents retreated at a distance of at least $10 \mathrm{~cm}$.

(2) Duration of each interaction in seconds.

(3) Latency time, the time elapsed between the divider removal and the first interaction.

(4) Dominance percentage. "Winner" was defined the crayfish that did not retreat or that retreated after that the opponent showed a motionless posture, which is proper of a subordinate (BRUSKI and DUNHAM, 1987). "Alpha" was the crayfish winning more than $50 \%$ of interactions in an hour.

(5) Six behavioural categories (BRUSKI and DUNHAM, 1987): approach (approaching, following), retreat (runaway, tailflip), visual displays (meral spread lunge), weak contacts (push, antenna tap), strong contacts (interlocked, chela strike), and status signals (body up, body down).

(6) Average score. We classified four types of interactions and scored them from 1 to 4, i.e. avoidances (retreats without any interaction), threats (retreats after visual displays), low intensity interactions (weak contacts), and high intensity interactions (strong contacts). The average score was computed as the sum of the scores of each interaction divided by the number of interactions.

(7) Agonistic level. It was calculated as the average score for every $10 \mathrm{~min}$ of observation.

\section{Statistics}

Since the assumptions of normality of data and homogeneity of variance were not always met and some data were measured on an ordinal scale, we used non-parametric tests following the procedures found in SIEGEL and CASTELLAN (1988). Independent samples were compared using MANN-WHITNEY U-tests (statistic: $U$ ) and KRUSKALLWALLIS analyses of variance (statistic: $\mathrm{H}$ ). We used FRIEDMAN two-way analyses of variance (statistic: $F_{r}$ ), followed by Multiple Comparisons tests, to compare related samples. Frequency data were analysed using G-tests (statistic: G). Text and figures give medians and interquartile ranges (first-third quartiles). The level of significance at which null hypothesis was rejected is $\alpha=0.05$. 


\section{RESULTS}

\section{Combat}

We did not find a significant decrease with the five days of combat in the number $\left(F_{r}=7.89\right.$, $d f=4$, n.s. $)$ and in the duration of interactions $\left(F_{r}=7.35, d f=4\right.$, n.s. $)$, in the number of behavioural patterns $\left(F_{r}=7.75, \mathrm{df}=4\right.$, n.s. $)$, in latency time $\left(F_{r}=8.52, \mathrm{df}=4\right.$, n.s.), and in the average score $\left(F_{r}=3.67, d f=4, n . s.\right)$. On the other hand, dominance percentage (always higher than $50 \%)$ significantly increased with time $\left(F_{r}=11.25\right.$, df $=4$, $P<0.05)$ (Figure 1). No dominance reversal ever occurred.
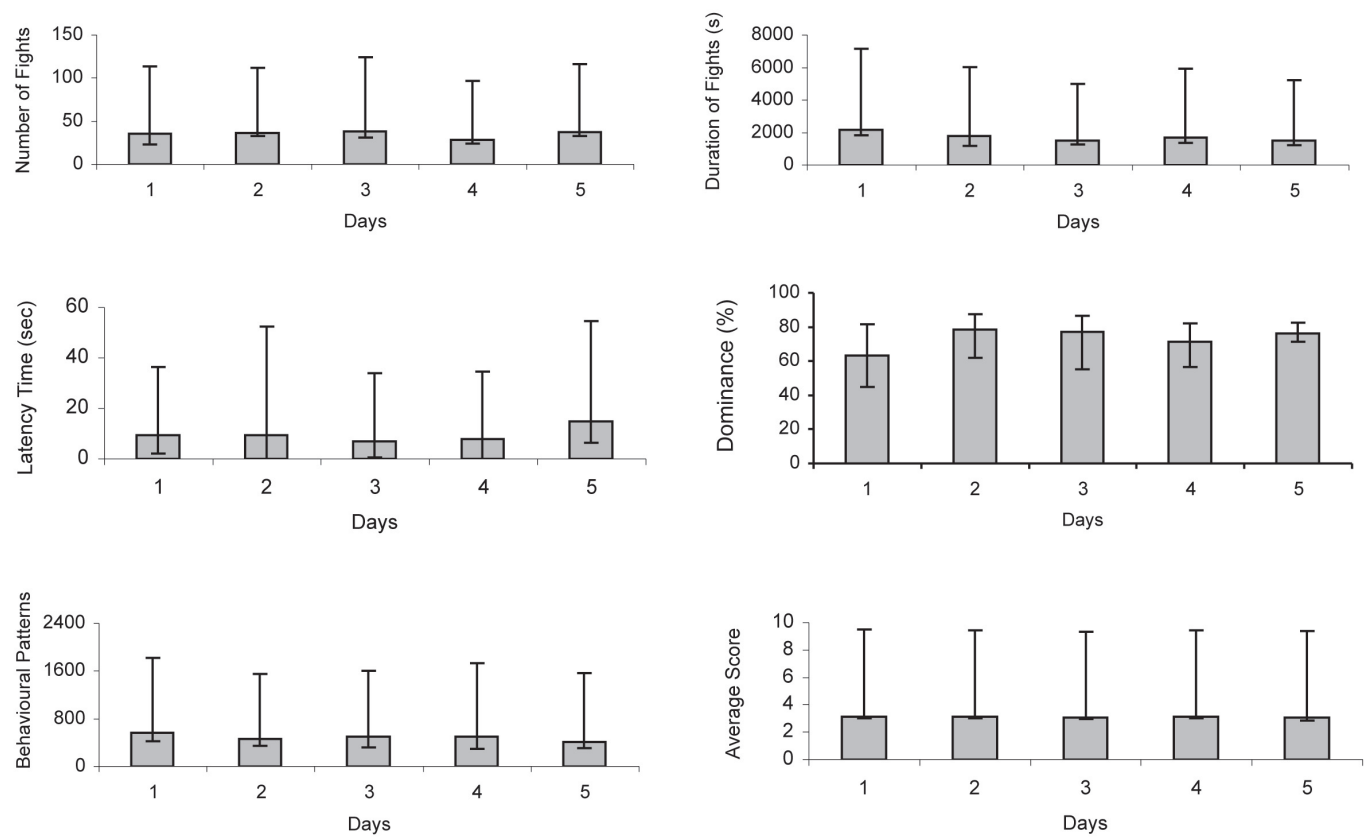

Figure 1

Number and duration of interactions, latency time, dominance, number of behavioural patterns, and average score of interactions per day during the five days of combat ( $\mathrm{n}$ is always 20 ).

Figure 1

Nombre et durée des interactions journalières, temps de latence, dominance, nombre de modèles de comportement, score moyen des interactions pendant les cinq jours de combat ( $\mathrm{n}$ est toujours 20 ).

The relative frequency of strong contacts showed a decrease during the five days of combat $\left(F_{r}=16.2\right.$, df $\left.=4, P<0.01\right)$, while retreats $\left(F_{r}=11.50, d f=4, P<0.05\right)$ and visual displays increased $\left(F_{r}=54.20, d f=4, P<0.001\right)$. On the contrary, the relative frequencies of approaches $\left(F_{r}=2.44\right.$, df $=4$, n.s. $)$, weak contacts $\left(F_{r}=2.60\right.$, df $=4$, n.s. $)$, and status signals $\left(F_{r}=3.89\right.$, df $=4$, n.s.) did not vary with time (Figure 2 ).

In all the days of combat (except Day 5), the number of interactions significantly decreased with time during the hour of observation (Day 1: $F_{r}=11.24$, df $=5, P<0.05$; Day 2: $F_{r}=10.43, d f=5, P$ ca. 0.05 ; Day 3: $F_{r}=23.58, \quad d f=5, P<0.001 ;$ Day 4: $F_{r}=26.64, d f=5, P<0.001$; Day 5: $F_{r}=9.10$, $d f=5$, n.s.), starting after the first 20 min of cohabitation (after Multiple Comparisons test, hierarchy: 0-10 $=10-20>20-30=30$ $40=40-50=50-60 \mathrm{~min}$ ) (Figure 3). A similar decrease with time was found in the agonistic 
level (Day 1: $F_{r}=30.28$; Day 2: $F_{r}=19.13$; Day 3: $F_{r}=21.14$; Day 4: $F_{r}=31.92$; Day 5: $F_{r}=22.73$, df $=5 ; P<0.001$ ) after the first 20 min (after Multiple Comparisons test: 0 $10=10-20>20-30=30-40=40-50=50-60 \mathrm{~min}$ ) (Figure 3).

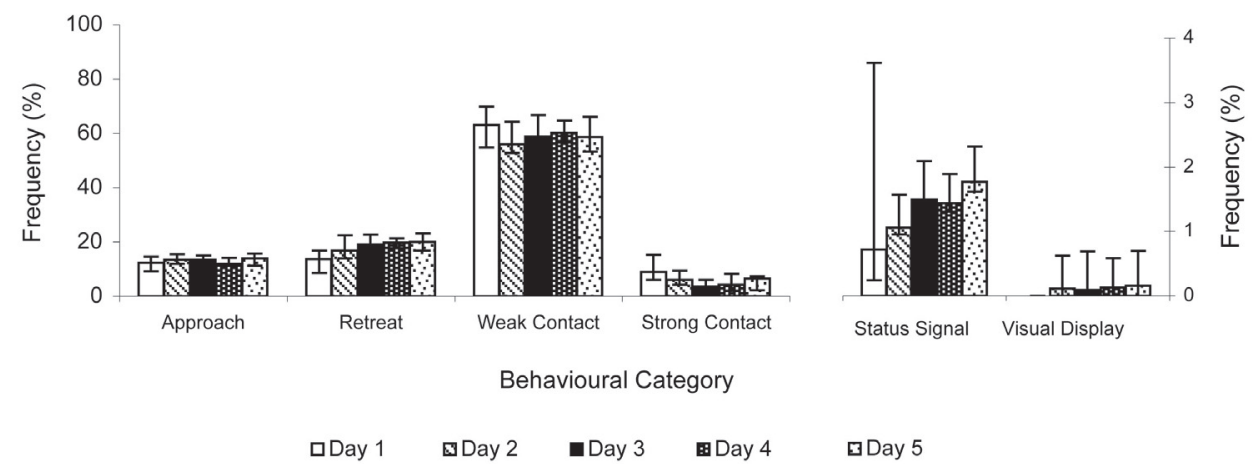

Figure 2

Daily frequency of the six behavioural categories during the five days of combat ( $n$ is always 20).

Figure 2

Fréquence journalière des six catégories de comportements pendant les cinq jours de combat (n est toujours 20).
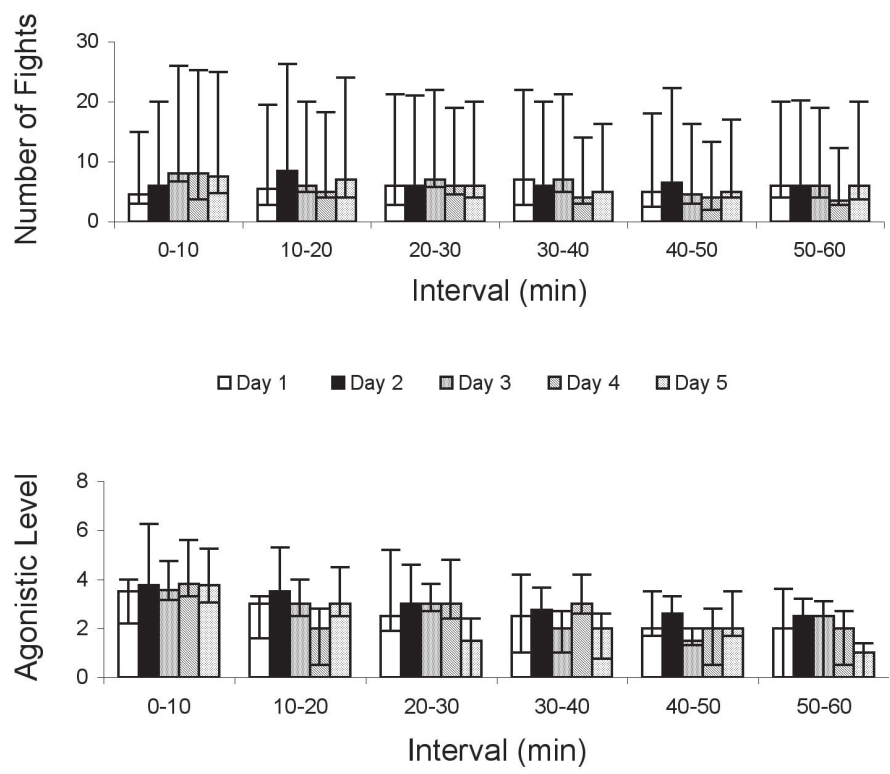

口Day $1 \square$ Day $2 \quad \square$ Day $3 \quad$ 口Day $4 \quad$ घDay 5

\section{Figure 3}

Changes during 1-h observation per day in the number of interactions and in the agonistic level for the five days of combat ( $n$ is always 20 ).

Figure 3

Nombre d'interactions pendant $1 \mathrm{~h}$ d'observation journalière et niveau agonistique, par jour, pendant les cinq jours de combat (n est toujours 20). 
To compare differences of behaviour between dominant (alpha) and subordinate (beta) individuals, we pooled the data from the 20 pairs and found that alphas executed a higher number of approaches, and weak and strong contacts, than the subordinates, while betas retreated more often than alphas $(G=1729.31$, $d f=5, P<0.001)$ (Figure 4).

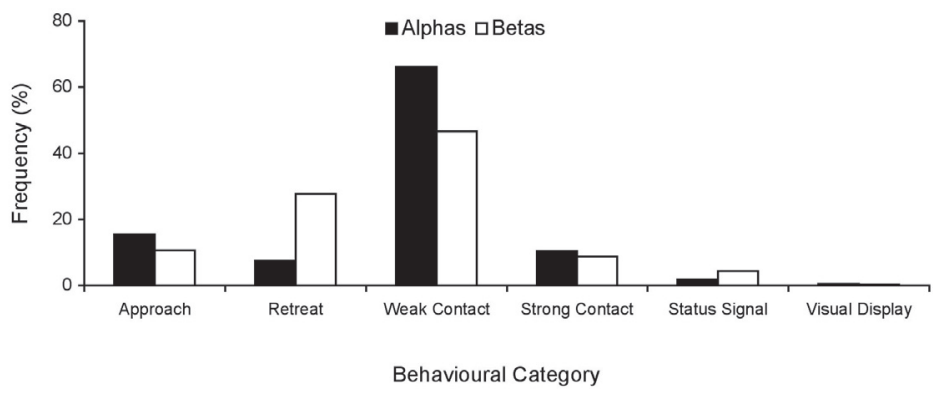

\section{Figure 4}

Frequency distribution of the behavioural categories compared between alphas and betas during the five days of combat ( $n$ is always 20 ).

\section{Figure 4}

Distribution des fréquences des catégories de comportement, comparées entre individus alphas et betas pendant les cinq jours de combat (n est toujours 20).
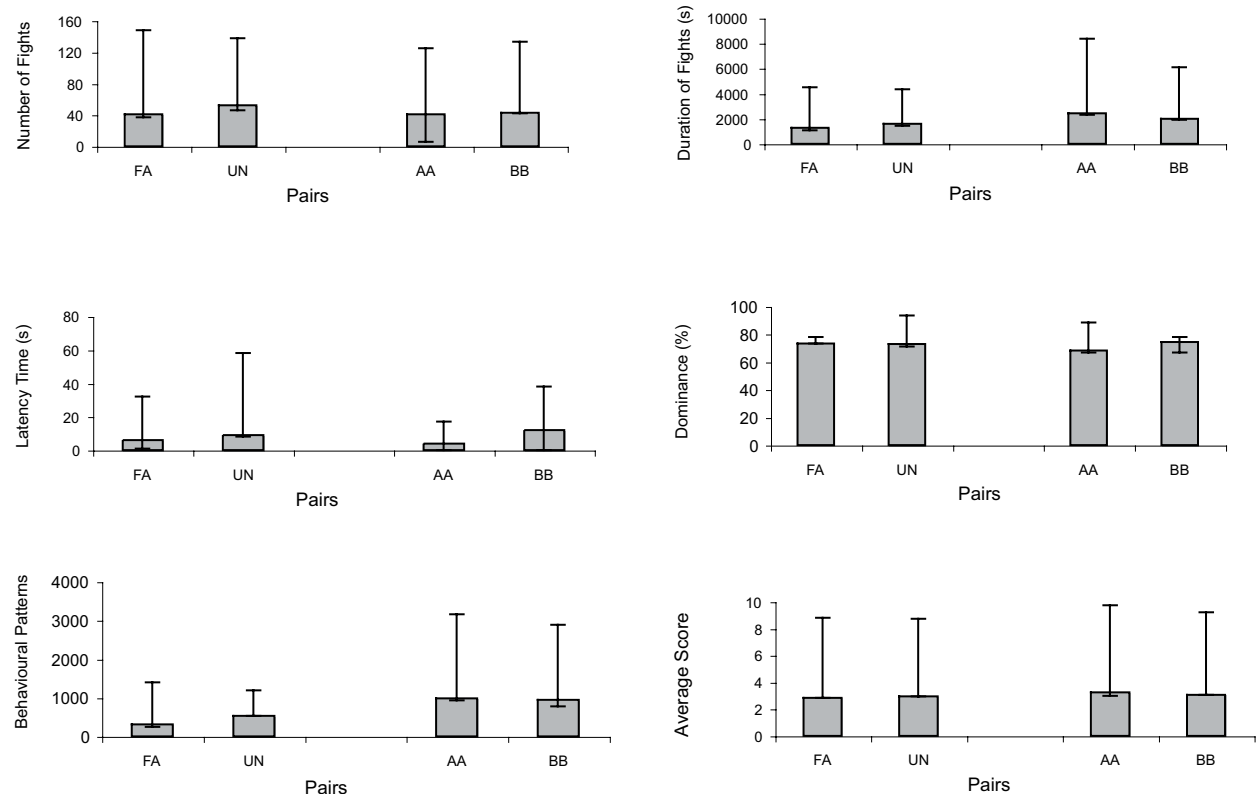

Figure 5

Number and duration of interactions, latency time, dominance, number of behavioural patterns, and average score of interactions recorded for the four treatments in the experimental phase: FA, familiar pairs $(n=5)$; UN, unfamiliar pairs $(n=5)$; AA, alpha-alpha pairs $(n=5)$; BB, beta-beta pairs $(n=5)$.

\section{Figure 5}

Nombre et durée des interactions, temps de latence, dominance, nombre de modèles comportementaux, et score moyen des interactions enregistrées pour les quatre types de traitement lors de la phase expérimentale: FA, paires de familiers $(n=5)$; UN, paires de non familiers $(n=5)$; AA, paires alpha-alpha $(n=5)$; BB, paires béta- béta $(n=5)$. 


\section{Experimental phase}

We did not find any significant difference between FA and UN pairs in any of the parameters analysed ( $U$ between 5.5 and 10.5, n.s.) with the exceptions of the total number of behavioural patterns $(U=4, P<0.05)$ (Figure 5) and approaches $(U=3$, $\mathrm{P}<0.05$ ) (Figure 6), which were both higher in UN pairs.

A significant difference was found between $A A$ and $B B$ pairs for the duration of interactions, which was longer in $A A$ pairs $(U=2, P<0.025)$ (Figure 5). The two types of pairs also differed for the number of retreats (higher in $B B$ pairs: $U=4, P<0.05$ ) and of strong contacts (higher in AA pairs: $U=0, P<0.005$ ) (Figure 6). Differences in the other behavioural patterns and in the other parameters were not significant ( $U$ between 6.5 and 11.5, n.s.).

Alphas and betas differed for the frequencies of the displayed behaviours (UN: $\mathrm{G}=462.88 ; \mathrm{FA}: \mathrm{G}=269.49 ; \mathrm{AA}: \mathrm{G}=293.99 ; \mathrm{BB}: \mathrm{G}=778.26, \mathrm{df}=5, \mathrm{P}<0.001)$. $\mathrm{A}$ comparison among the four treatments revealed that dominant $(H=10.98, d f=3$, $\mathrm{P}<0.02)$ and subordinate $(\mathrm{H}=11.86, \mathrm{df}=3, \mathrm{P}<0.01)$ crayfish executed strong contacts in AA pairs more often than in the other treatments (for the other behavioural patterns: $\mathrm{H}$ between 2.61 and 5.58, $\mathrm{df}=3$, n.s.).

Subordinates more often displayed status signals in FA pairs $(H=8.77, d f=3$, $P<0.05)$, the other behavioural patterns being the same $(H$ between 2.34 and $6.30, d f=3$, n.s.) (Figure 7).
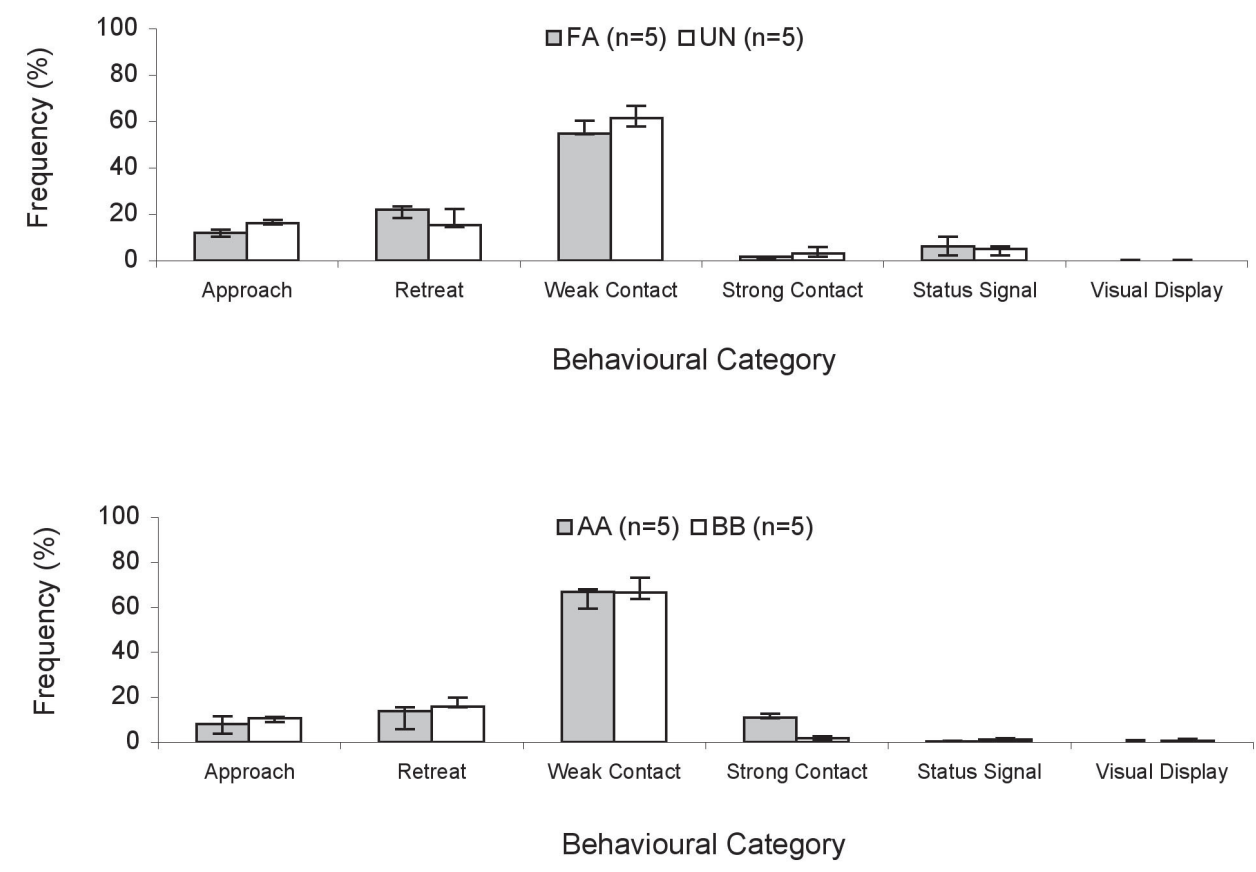

Figure 6

Frequency distribution of the behavioural categories compared among the four treatments (FA, UN, AA, BB) of the experimental phase.

\section{Figure 6}

Distribution des fréquences des catégories de comportement, comparées entre les quatre types de traitements (FA, UN, AA, BB) lors de la phase expérimentale. 


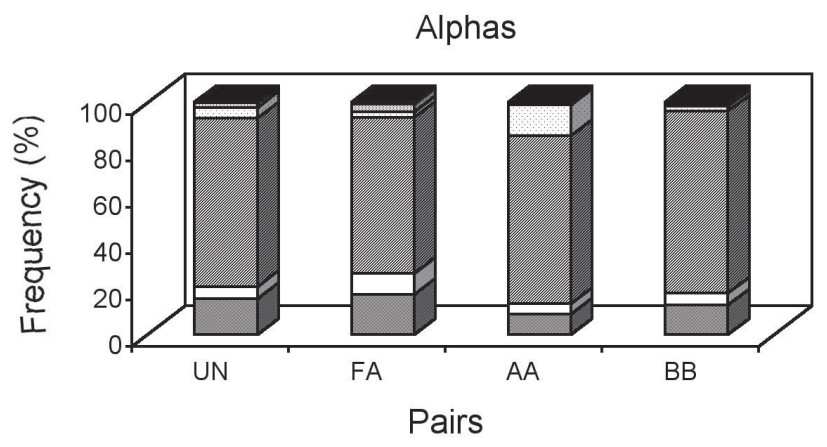

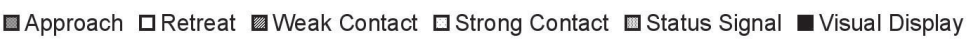

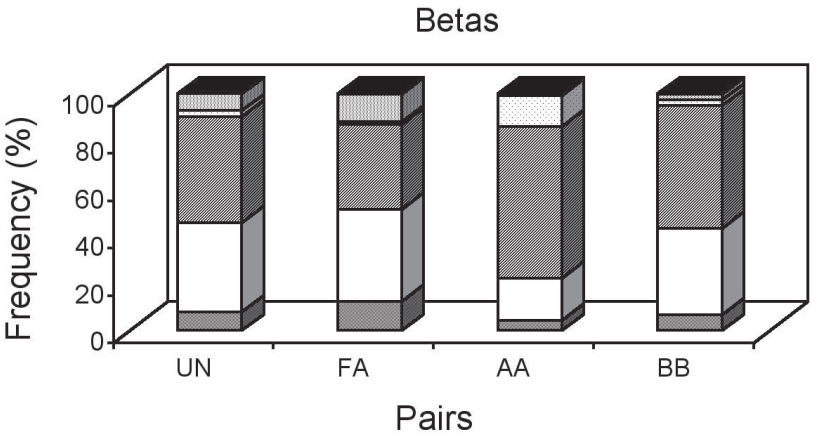

$\square$ Approach $\square$ Retreat $\square$ Weak Contact $\square$ Strong Contact $\square$ Status Signal $\square$ Visual Display

\section{Figure 7}

Frequency distribution of the behavioural categories compared between alphas and betas among the four treatments (FA, UN, AA, BB) of the experimental phase.

\section{Figure 7}

Distribution des fréquences des catégories comportementales comparées entre individus alphas et betas sur les quatre traitements (FA, UN, AA, BB) lors de la phase expérimentale.

\section{Discussion}

Similarly to the other crayfish species so far studied (Procambarus clarkii: COPP, 1986; Orconectes rusticus: ZULANDT SCHNEIDER et al., 2001; Procambarus acutus acutus: GHERARDI and DANIELS, 2003), size-matched pairs of male A. italicus form stable dominance hierarchies, at least under laboratory conditions. In our experiments, a polarity in the behaviour of dominant and subordinate individuals appeared soon, after the first 20 minutes of cohabitation, and increased from the first to the fifth day of combat. As expected, hierarchy formation results in mitigating aggressiveness between combatants. In fact, on the one hand, the number and the duration of interactions remained constant with time. On the other hand, a significant change in interaction intensity (but not in the average score) was recorded. The overall number of behavioural patterns did not vary with time; however, the execution of strong contacts decreased and the occurrence of retreats and visual displays increased. As suggested by GUHL $(1958,1968)$, the phenomenon of "social inertia" is at the basis of these changes: hierarchies play the role of reducing both time and energy consumption of fighting and risks of death or injury. 
After having subjected pairs to the experimental switch, we did not record any dominance reversal in UN pairs. Previous winners and losers showed the same behaviour as in the combat phase. Also, all the analysed parameters (with the exception of the total number of behaviours) did not vary between FA and UN pairs. This, on the one hand, excludes the ability of $A$. italicus to recognise the opponents as individuals and, on the other, supports the hypothesis that hierarchies are maintained stable in this species by a form of status recognition and/or by "winner and loser" effects. The results of AA and BB treatments proved that these two mechanisms can coexist in A. italicus. Notwithstanding that, at the end of combat, a clear hierarchy was formed in both types of pairs, interactions were shorter in $\mathrm{BB}$ and the two combatants more often retreated than in AA. Besides, both rivals of $A A$ executed strong contacts more often than the combatants of all the other pairs.

Our conclusion is that, as already hypothesised for Procambarus acutus acutus (GHERARDI and DANIELS, 2003), A. italicus adopts two mechanisms to maintain hierarchies, i.e. status recognition and "winner and loser" effects. Similarly to other freshwater decapods (Potamon fluviatile: GHERARDI et al., 1998; Procambarus clarkii: GHERARDI and BARBARESI, 2000), A. italicus shows a low degree of site fidelity, making use of "ephemeral" home ranges (ROBINSON et al., 2000). Therefore, encounters between the same crayfish are unlikely and any "expensive" form of individual recognition appears useless. Status recognition and "winner and loser "effects are, on the contrary, "cheap" and efficient with respect to $A$. italicus'behavioural ecology. Both permit dominant crayfish to first accede to resources (food, shelter or mate) and subordinates to avoid costs from fighting.

As emphasised by SUTHERLAND (1998), the knowledge of social behaviour in species of conservation concern is of great relevance. In the case of $A$. italicus, for instance, it helps understand the appropriate density of the reintroduced or cultured population that does not lead to a dangerous increase of intraspecific agonism.

\section{REFERENCES}

BOAL J.G., 1996. Absence of social recognition in laboratory-reared cuttlefish, Sepia officinalis L. (Mollusca: Cephalopoda). Anim. Behav., 44, 547-555.

BRUSKI C., DUNHAM D.W., 1987. The importance of vision in agonistic communication of the crayfish Orconectes rusticus. An analysis of bout dynamics. Behaviour, 103, 83-107.

CALDWELL R.L., 1979. Cavity occupation and defensive behaviour in the stomatopod Gonodactylus festae: evidence for chemically mediated recognition. Anim. Behav., 27, 294-301.

CALDWELL R.L., 1985. A test of individual recognition in the stomatopod Gonodactylus festae. Anim. Behav., 33, 101-106.

COPP N., 1986. Dominance hierarchies in the crayfish Procambarus clarkii and the question of learned individual recognition. Crustaceana (Leiden), 51, 9-24.

DREWS C., 1993. The concept and definition of dominance in animal behavior. Behaviour, 125, 283-313.

DUGATKIN L.A., 1997. Winner and loser effects and structure of dominance hierarchies. Behav. Ecol., 8, 583-587.

FRANCIS R.C., 1998. On the relationships between aggression and social dominance. Ethology, 78, 223-237.

GHERARDI F., TARDUCCI F., VANNINI M., 1998. Locomotor activity in the freshwater crab Potamon fluviatile: the analysis of temporal patterns by radio-telemetry. Ethology, 77, 300-316. 
GHERARDI F., BARBARESI S., 2000. Invasive crayfish: activity patterns of Procambarus clarkii in the rice fields of the Lower Guadalquivir (Spain). Arch. Hydrobiol., 150, 153-168.

GHERARDI F., 2002. Chpt. 7. Behavior. In: D. M. HOLDICH (Ed.) Biology of freshwater crayfish. Blackwell Science Ltd., Oxford, pp. 258-290.

GHERARDI F., DANIELS W.H., 2003. Dominance hierarchies and status recognition in the crayfish Procambarus acutus acutus. Can. J. Zool., 81, 1269-1281.

GHERARDI F., TIEDEMANN J., 2004. Binary individual recognition in hermit crabs. Behavioral Ecology and Sociobiology, 55, 524-530.

GUHL A.M., 1958. The development of social organisation in the domestic chick. Anim. Behav., 6, 92-111.

GUHL A.M., 1968. Social inertia and social stability in chickens. Anim. Behav., 16, 219232.

GUIASU R.C., DUNHAM D.W., 1999. Agonistic contests in male form I Cambarus bartoni (Fabricius, 1789) (Decapoda, Cambaridae) crayfish and comparison with contests of the same type in Cambarus robustus Girard, 1852. Crustaceana (Leiden), 72, 1079-1091.

HAZLETT B.A., 1969. "Individual" recognition and agonistic behaviour in Pagurus bernhardus. Nature (Lond.), 222, 180-181.

HUBER M.E., 1987. Aggressive behavior of Trapezia intermedia Miers and T. digitalis Latreille (Brachyura: Xanthidae). J. Crustac. Biol., 7, 238-248.

KARAVANICH C., ATEMA J., 1998. Individual recognition and memory in lobster dominance. Anim. Behav., 56, 1553-1560.

LOWE M.E., 1956. Dominance-subordinate relationships in the crawfish Cambarellus shufeldtii. Tulane Stud. Zool., 4, 139-170.

ROBINSON C.A., THOM T.J., LUCAS M.C., 2000. Ranging behaviour of a large freshwater invertebrate, the white-clawed crayfish Austropotamobius pallipes. Freshw. Biol., $44,509-521$.

SIEGEL S., CASTELLAN N.J., Jr., 1988. Nonparametric statistics for the behavioural sciences. McGraw-Hill, New York.

STEINBERG J.E., CONANT R.C., 1974. An informational analysis of the inter-male behaviour of the grasshopper Chortophaga viridifasciata. Anim. Behav., 22, 617-627.

SUTHERLAND W.J., 1998. The importance of behavioural studies in conservation biology. Anim. Behav., 56, 801-809.

VANNINI M., GHERARDI F., 1981. Dominance and individual recognition in Potamon fluviatile (Decapoda: Brachyura): possible role of visual cues. Mar. Behav. Phys., 8, 13-20.

WILSON E.O., 1975. Sociobiology, the new synthesis. Belknap Press. Cambridge, Mass.

WINSTON M., JACOBSON S., 1978. Dominance and effects of strange conspecifics on aggressive interactions in hermit crab Pagurus longicarpus. Anim. Behav., 26, 184191.

ZULANDT SCHNEIDER R.A., HUBER R., MOORE P.A., 2001. Individual and status recognition in the crayfish, Orconectes rusticus: the effects of urine release on fight dynamics. Behaviour, 138, 137-153. 